\title{
STUDI KELAYAKAN DAN DESAIN PEMANFAATAN SUMBER ENERGI TERBARUKAN DI KAMPUNG TUA TANJUNG GUNDAP, BATAM
}

\author{
Chaeriah Bin Ali Wael dan Wilda Fasim Hasibuan \\ Dosen Tetap Universitas Riau Kepulauan Batam
}

\section{INTISARI}

Kampung Tua Tanjung Gundap merupakan salah satu pemukiman warga Melayu di Batam yang telah dihuni selama beberapa generasi. Sama halnya dengan desa-desa pesisir lainnya di pulau Batam, Tanjung Gundap juga belum terjangkau fasilitas listrik dan hanya mengandalkan genset yang beroperasi selama kurang lebih 6 jam dalam sehari. Pemanfaatan energi terbarukan untuk elektrifikasi dapat menjadi sebuah solusi. Potensi energi terbarukan berupa energi angin, surya dan pasang surut air laut yang dimiliki desa ini cukup berlimpah.Metode penelitian yang dipakai adalah pengukuran untuk kecepatan angin dan pasang surut air laut. Survei dan wawancara langsung untuk kelayakan sosial, ekonomi dan budaya. Hasil yang dicapai dari pengukuran kecepatan angin dan pasang surut air laut diperoleh 51,02 Kwatt. Sedangkan kebutuhan listrik di Tanjung Gundap 72,21 Kwatt. Maka perancangan elektrifikasi alternatif belum cocok di Tanjung Gundap. Sedangkan kelayakan sosial, ekonomi dan budaya juga belum relevan karena beberapa alasan: insfrastruktur, tata letak, sanitasi, akses transportasi.

Kata kunci:

Energi baru terbarukan, elektrifikasi, sosial, ekonomi dan budaya.

\section{PENDAHULUAN}

Pertumbuhan ekonomi dan pertambahan penduduk mendorong meningkatnya permintaan energi di Indonesia. Ironisnya, sumber energi konvensional berupa energi fosil yang menjadi sumber energi utama di Indonesia semakin terbatas cadangannya. Di samping itu, harga energi fosil bersifat fluktuatif karena dipengaruhi oleh situasi politik dan ekonomi dunia. Dalam kondisi seperti ini, kebijakan konservasi dan diversifikasi energi yang telah dicanangkan oleh pemerintah merupakan kebijakan yang tepat untuk diterapkan di Indonesia. Pengembangan energi baru terbarukan (EBT) sebagai komplementer energi fosil bersifat mutlak untuk terus dilaksanakan. Potensi energi terbarukan di Indonesia seperti biomasa, panas bumi, energi surya, energi air, energi angin dan energi samudera sebenarnya sangat besar. Namun sampai saat ini, pemanfaatannya masih sangat kecil.

Sebagai salah satu wilayah perbatasan di Indonesia, Batam merupakan salah satu kota dengan tingkat pertumbuhan ekonomi yang tinggi dan telah memberi kontribusi yang cukup besar bagi pembangunan nasional. Sejak pulau Batam dan beberapa pulau di sekitarnya dikembangkan menjadi daerah industri, perdagangan dan pariwisata, laju pertumbuhan penduduk terus meningkat. Dari hasil sensus penduduk 2010, selama periode 2000-2010, 
laju pertumbuhan penduduk rata-rata kota Batam adalah sebesar $8,1 \%$, dimana sebagian besar merupakan para pekerja yang berasal dari berbagai daerah di Indonesia. Sampai saat ini, arus pendatang dari berbagai daerah di Indonesia tidak pernah putus.

Pengelola kelistrikan di Batam adalah PLN tetapi bukan Perusahaan Listrik Negara. PLN Batam kependekan dari Pelayanan Listrik Nasional Batam. PLN Batam yang merupakan anak perusahaan PT PLN (Persero), merupakan perusahaan swasta yang menyediakan tenaga listrik bagi kepentingan umum khusus bagi Pulau Batam. Selain PLN Batam, terdapat beberapa perusahaan listrik swasta lain yang beroperasi di daerah ini namun hanya PLN Batam yang berkewajiban untuk memasok listrik bagi masyarakat Batam. Sementara perusahaan listrik swasta lain lebih banyak menyuplai listrik bagi usaha industri. Pada awal pengelolaan listrik oleh PLN Batam, perusahaan tersebut dianggap belum maksimal dalam melistriki Pulau Batam. Tetapi belakangan, kinerja PLN Batam dinilai semakin membaik. Rasio elektrifikasi di Kota Batam dari waktu ke waktu terus meningkat. Saat ini, rasio elektrifikasi di Batam sudah mencapai $90 \%$ lebih.

Tanjung Gundap merupakan salah satu kampung tua di Batam dengan penduduk yang sebagian besar berprofesi sebagai nelayan karena memang secara geografis kampung ini terletak di pesisir pantai. Walaupun dapat dijangkau hanya dalam waktu kurang dari 15 menit dari pusat kota Batam, Tanjung Gundap masih belum teraliri listrik karena tidak terjangkau jaringan listrik PLN Batam. Warga Tanjung Gundap hanya mengandalkan sumber energi listrik dari genset yang tidak mampu melayani kebutuhan warga secara keseluruhan. Beberapa kepala keluarga bahkan tidak mampu membayar karena mahalnya tarif yang dibebankan hanya untuk menikmati listrik selama 6 jam dalam sehari. Karena itulah diperlukan terobosan untuk penyediaan energi listrik alternatif dengan memanfaatkan sumber-sumber energi terbarukan yang tersedia di daerah tersebut.

Tujuan penelitian ini adalah untuk menggali bagaimana potensi energi terbarukan di Kampung Tua Tanjung Gundap dan apakah kondisi sosio-ekonomi-budaya masyarakat Tanjung Gundap relevan dengan sistem elektrifikasi hibrid. 


\section{TINJAUAN PUSTAKA}

Angin adalah salah satu sumber energi baru dan terbarukan yang dapat dimanfaatkan langsung oleh masyarakat untuk memenuhi kebutuhan energi, khususnya di daerah pedesaan dan daerah terpencil. Salah satu pemanfaatan potensi energi angin adalah untuk menggerakan kincir angin/turbin angin. Kincir angin tersebut dapat menggerakan generator untuk menghasilkan listrik atau dapat pula menggerakan pompa air untuk memompa air tanah. Berdasarkan data Ditjen Listrik dan Pemanfaatan Energi, potensi tenaga angin sekitar 3-5 m/detik (9.287 MW) sedangkan kapasitas yang sudah terpasang hanya sekitar 0,5 MW.

Tenaga yang dihasilkan angin berbanding lurus dengan pangkat tiga kecepatan angin sebagaimana ditunjukkan pada persamaan 1 .

$\mathrm{P}=1 / 2 \times \mathrm{C} \times \varsigma \times v^{3}$

Dengan : $\quad P$ : Daya angin $\left(\mathrm{W} / \mathrm{m}^{2}\right) \mathrm{C}: 16 / 27$

$\varsigma:$ Densitas udara $=1,18 \mathrm{Kg} / \mathrm{m}^{2}$

$\mathrm{v}:$ Kecepatan angin $(\mathrm{m} /$ detik)

Energi laut atau samudra adalah energi yang dapat dihasilkan dari konversi gaya mekanik, gaya potensial serta perbedaan temperatur air laut menjadi energi listrik. Energi samudra murni dapat digolongkan menjadi empat jenis yaitu energi gelombang (wave power), energi pasang surut (tidal power), energi arus laut (current power) dan energi panas laut (ocean thermal energy conversion, OTEC). Energi pasang surut adalah energi kinetik dari pemanfaatan beda ketinggian pasang permukaan laut antara saat pasang dan surut. Prinsip kerja dari energi pasang surut ini sama dengan pembangkit listrik tenaga air (PLTA).

Energi yang dihasilkan dalam satu siklus pasang surut dapat dihitung dengan rumus pada persamaan (3) dan (4).

$$
\begin{aligned}
& \text { Emaks }=\text { b.g. } \mathrm{H}^{2} \cdot \mathrm{S} \\
& \mathrm{P} \quad=\mathrm{f} . \mathrm{Q} \cdot \mathrm{H}
\end{aligned}
$$

Dengan :

Emaks : Jumlah energi maksimum yang dapat diproses per

siklus b : Berat jenis air laut

g : Gravitasi

$\mathrm{H} \quad$ : Tinggi pasang surut terbesar

S : Luas waduk 


$\begin{array}{ll}\mathrm{P} & : \text { Daya } \\ \mathrm{f} & : \text { Faktor efisiensi } \\ \mathrm{Q} & : \text { Debit air }\end{array}$

Secara sosial, ekonomi, pada hakikatnya manusia harus memenuhi kebutuhan dasar terlebih dahulu sebelum meningkat ke kebutuhan selanjutnya. Secara umum, seseorang tidak akan memikirkan hal-hal lain jika kebutuhan perut dan anggota fisiknya tidak terpenuhi. Kebutuhan dasar itu meliputi udara, air, protein, garam, kalsium dan mineral vitamin lainnya (didapat dari makanan pokok). Kebutuhan dasar juga termasuk pH balance, suhu udara, kebutuhan istirahat, tidur, membuang kotoran dan have sex.

Kebutuhan energi listrik termasuk pada need physiological yang berhubungan dengan kebutuhan-kebutuhan pokok dan mendasar. Dalam penelitian lainnya hanya terdapat dua need pada manusia, need biological termasuk listrik dan lainnya. Pada zaman modern, listrik sangat dibutuhkan pada semua sisi kehidupan khususnya kehidupan sehari- hari. Pada prakteknya listrik diharuskan memberikan keuntungan bagi kesehatan, well- being, pengembangan diri. Bagi masyarakat yang menetap di wilayah kepulauan, listrik merupakan kebutuhan mahal. Hal ini disebabkan tidak terjangkaunya listrik PLN ke daerah yang berbatasan dengan laut. Jika energi listrik dapat diciptakan dari sumber daya alam tempatan maka biaya hidup dapat ditekan. Dengan menekan biaya hidup, geliat ekonomi masyarakat akan berkembang. Sejurus dengan itu masyarakat tidak akan berkutat pada level kebutuhan dasar saja.

Kebutuhan dasar manusia harus terpenuhi sehingga pengembangan wilayah, sosial, ekonomi dan budaya dapat dikembangkan. Adapun indikator yang harus dipenuhi dalam analisis ini adalah:

a. Perumahan yang layak dan sehat

b. Sumber air bersih yang mudah terjangkau

c. Sanitasi yang ideal

d. Tingkat pendidikan penduduk setempat

e. Keamanan

f. Local Identity

\section{METODE}

Langkah-langkah dalam penelitian ini dapat dilihat pada gambar 4.2. Tahap awal penelitian dimulai dengan perumusan masalah yang akan diteliti kemudian dilanjutkan 
dengan studi literatur yang mendukung penyelesaian masalah yang akan diteliti. Tahap pelaksanaan terdiri atas proses pengumpulan data yang diperoleh dari hasil pengukuran lapangan dan wawancara. Selanjutnya dilakukan analisa kelayakan dan sosioekonomi masyarakat setempat dengan kuisioner. Dari hasil analisa, selanjutnya disusun rekomendasi-rekomendasi berkaitan dengan pemanfaatan energi terbarukan untuk tujuan elektrifikasi di daerah Tanjung Gundap, Batam.

Secara terperinci, desain penelitian yang akan dilakukan adalah sebagai berikut :

1. Merumuskan masalah.

2. Survey potensi energi terbarukan.

3. Menentukan data-data literatur.

4. Melakukan korespondensi dengan Ketua RW, masyarakat setempat dan pihak-pihak terkait dengan penelitian ini.

Melakukan penelitian langsung selama beberapa periode untuk mengumpulkan data- data sesuai dengan laporan kemajuan penelitian.

Pengumpulan data dilakukan dengan dua cara:

Melalui survei langsung dan wawancara

Untuk mendapatkan informasi Kampung Tua Tanjung Gundap dengan mewawancarai Ketua RW setempat. hari.

Untuk mendapatkan informasi data penggunaan peralatan listrik sehari-

Untuk mendapatkan informasi mengenai pengoperasian dan biaya penggunaan Pembangkit Listrik Tenaga Diesel (PLTD) dengan mewawancarai penyedia jasa layanan tenaga listrik.

Pengukuran pasang-surut air laut, untuk memperoleh kondisi dan sifat-sifat fisik air laut berupa beda ketinggian ketika air laut pasang dan surut.

5. Melakukan analisis data dengan rumus pasang surut air laut dan kecepatan angin.

6. Menganalisis data survei kelayakan sosial, ekonomi dan budaya dengan Teori analisis sosial, ekonomi dan budaya dari beberapa sumber.

7. Kesimpulan dan rekomendasi penelitian dalam usaha peningkatan penyediaan tenaga listrik di Kampung Tua Tanjung Gundap. 


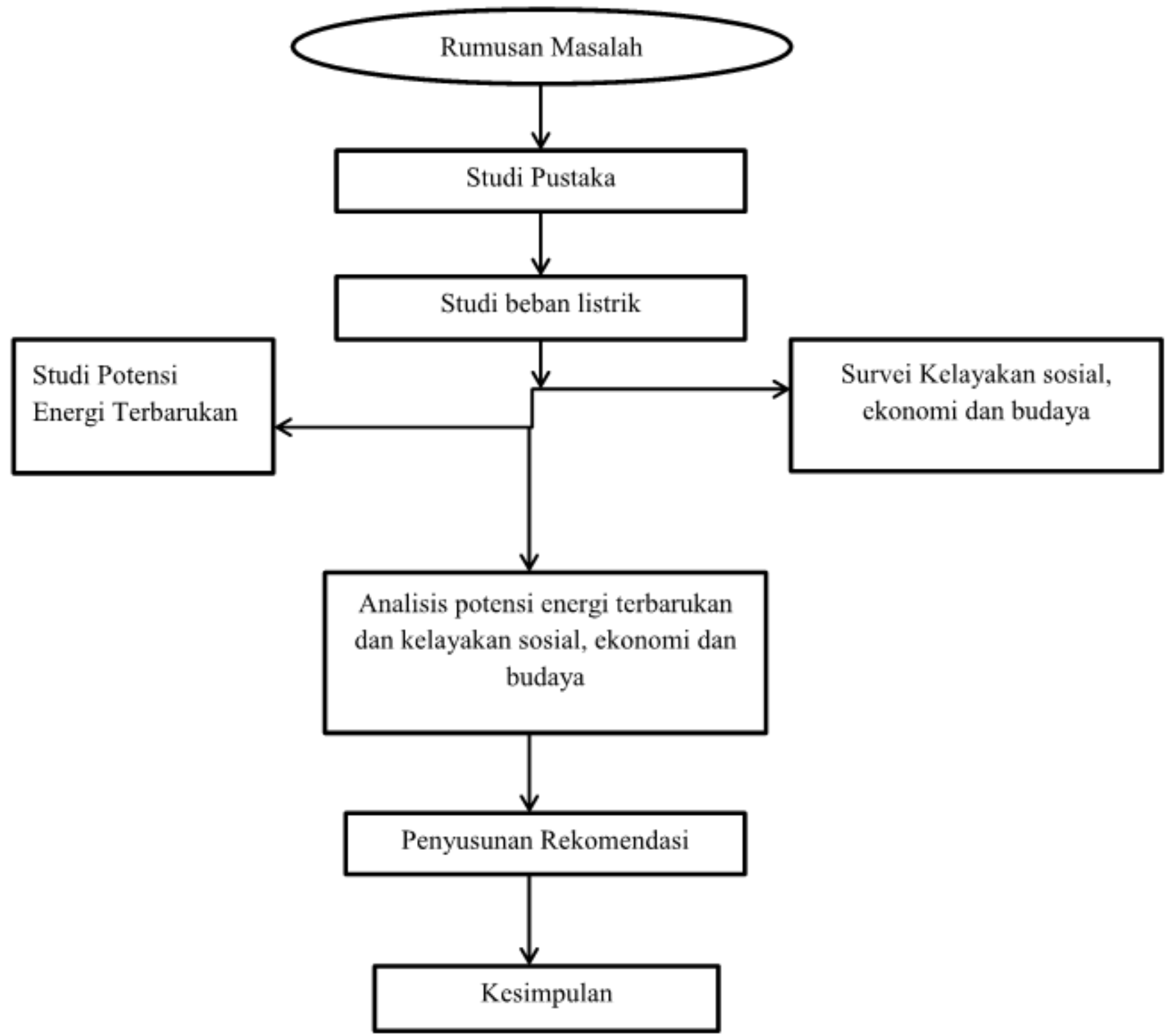

paаa puкuı ı masyarakat Tanjung Gundap mati. Biasanya listrik hanya menyala 6 jam perhari.

Dapat disimpulkan bahwa beban puncak masyarakat Kampung Tua Tanjung Gundap berdasarkan data adalah $0.83 \mathrm{~kW}$. Kemudian dikalikan 87 rumah. Sehingga beban listrik yang dibutuhkan setiap hari adalah 72,21 kW/87 rumah.

\section{Studi Potensi Energi Terbarukan}

Energi terbarukan yang diambil datanya adalah ketinggian energi pasang surut, suhu udara dan energi angin. Data dapat dilihat pada table di bawah ini:

\section{Analisis Potensi Energi Pasang Surut}




\begin{tabular}{|c|c|c|c|c|c|c|c|}
\hline $\begin{array}{l}\text { Ta } \\
\text { ng } \\
\text { gal }\end{array}$ & Pukul & $\begin{array}{c}\text { Tinggi } \\
\text { Gelom } \\
\text { bang }\end{array}$ & $\begin{array}{c}\text { Keteran } \\
\text { gan }\end{array}$ & $\begin{array}{l}\text { Selisish } \\
\text { pasang } \\
\text { surut } \\
\text { air laut } \\
\text { (m) } \\
\end{array}$ & $\begin{array}{l}\text { Faktor } \\
\text { effisiensi } \\
=\mathbf{8 0 \%}\end{array}$ & $\begin{array}{c}\text { Debit Air } \\
\text { (m3/detik) }\end{array}$ & $\begin{array}{c}\text { Daya yang } \\
\text { dihasilkan } \\
\text { (Kwatt) }\end{array}$ \\
\hline \multirow[t]{2}{*}{1} & $10.40 \mathrm{AM}$ & $2.2 \mathrm{~m}$ & Pasang & 1,2 & 0,8 & 20 & 19,2 \\
\hline & $15.50 \mathrm{PM}$ & $1 \mathrm{~m}$ & Surut & & & & \\
\hline \multirow[t]{2}{*}{2} & $11.20 \mathrm{AM}$ & $2,7 \mathrm{~m}$ & Pasang & 1,7 & 0,8 & 20 & 27,2 \\
\hline & 16.40 PM & $1 \mathrm{~m}$ & Surut & & & & \\
\hline \multirow[t]{2}{*}{3} & $11.55 \mathrm{AM}$ & $3 \mathrm{~m}$ & Pasang & 2,1 & 0,8 & 20 & 33,6 \\
\hline & $16.55 \mathrm{PM}$ & $0,9 \mathrm{~m}$ & Surut & & & & \\
\hline \multirow[t]{2}{*}{4} & $12.40 \mathrm{AM}$ & $3 \mathrm{~m}$ & Pasang & 2,1 & 0,8 & 20 & 33,6 \\
\hline & $17.25 \mathrm{PM}$ & $0.9 \mathrm{~m}$ & Surut & & & & \\
\hline \multirow[t]{2}{*}{5} & $06.40 \mathrm{AM}$ & $0 \mathrm{~m}$ & Surut & 3 & 0,8 & 20 & 48 \\
\hline & $12.55 \mathrm{PM}$ & $3 \mathrm{~m}$ & Pasang & & & & \\
\hline \multirow[t]{2}{*}{6} & $07.40 \mathrm{AM}$ & $0 \mathrm{~m}$ & Surut & 2,8 & 0,8 & 20 & 44,8 \\
\hline & $13.40 \mathrm{PM}$ & $2,8 \mathrm{~m}$ & Pasang & & & & \\
\hline \multirow[t]{2}{*}{7} & $08.30 \mathrm{AM}$ & $0.3 \mathrm{~m}$ & Surut & 2,5 & 0,8 & 20 & 40 \\
\hline & 14.40 PM & $2,8 \mathrm{~m}$ & Pasang & & & & \\
\hline \multirow[t]{2}{*}{8} & $09.20 \mathrm{AM}$ & $0,2 \mathrm{~m}$ & Surut & 2,5 & 0,8 & 20 & 40 \\
\hline & $15.40 \mathrm{PM}$ & $2,7 \mathrm{~m}$ & Pasang & & & & \\
\hline \multirow[t]{2}{*}{9} & $10.10 \mathrm{AM}$ & $0,5 \mathrm{~m}$ & Surut & 2,2 & 0,8 & 20 & 35,2 \\
\hline & 16.25 PM & $2,7 \mathrm{~m}$ & Pasang & & & & \\
\hline \multirow[t]{2}{*}{10} & $11.10 \mathrm{AM}$ & $0,8 \mathrm{~m}$ & Surut & 2 & 0,8 & 20 & 32 \\
\hline & $17.40 \mathrm{PM}$ & $2,8 \mathrm{~m}$ & Pasang & & & & \\
\hline \multirow[t]{2}{*}{11} & $06.20 \mathrm{AM}$ & $2 \mathrm{~m}$ & Pasang & 1,2 & 0,8 & 20 & 19,2 \\
\hline & $12.10 \mathrm{AM}$ & $0,8 \mathrm{~m}$ & Surut & & & & \\
\hline \multirow[t]{2}{*}{12} & $07.40 \mathrm{AM}$ & $2 \mathrm{~m}$ & Pasang & 1 & 0,8 & 20 & 16 \\
\hline & 13.20 PM & $1 \mathrm{~m}$ & Surut & & & & \\
\hline \multirow[t]{2}{*}{13} & 08.45AM & $2 \mathrm{~m}$ & Pasang & 1 & 0,8 & 20 & 16 \\
\hline & 14.20 PM & $1 \mathrm{~m}$ & Surut & & & & \\
\hline \multirow[t]{2}{*}{14} & $09.50 \mathrm{AM}$ & $2 \mathrm{~m}$ & Pasang & 1 & 0,8 & 20 & 16 \\
\hline & $15.15 \mathrm{PM}$ & $1 \mathrm{~m}$ & Surut & & & & \\
\hline
\end{tabular}




\begin{tabular}{|c|c|c|c|c|c|c|c|}
\hline 15 & $10.55 \mathrm{AM}$ & $2 \mathrm{~m}$ & Pasang & 1 & 0,8 & 20 & 16 \\
\hline & $15.55 \mathrm{PM}$ & $1 \mathrm{~m}$ & Surut & & & & \\
\hline \multirow[t]{2}{*}{16} & $11.20 \mathrm{AM}$ & $2.5 \mathrm{~m}$ & Pasang & 1,7 & 0,8 & 20 & 27,2 \\
\hline & $16.45 \mathrm{PM}$ & $0,8 \mathrm{~m}$ & Surut & & & & \\
\hline \multirow[t]{2}{*}{17} & $11.55 \mathrm{AM}$ & $3 \mathrm{~m}$ & Pasang & 2,1 & 0,8 & 20 & 33,6 \\
\hline & $17.40 \mathrm{PM}$ & $0,9 \mathrm{~m}$ & Surut & & & & \\
\hline \multirow[t]{2}{*}{18} & $12.25 \mathrm{PM}$ & $2,8 \mathrm{~m}$ & Pasang & 2,1 & 0,8 & 20 & 33,6 \\
\hline & $17.55 \mathrm{PM}$ & $0,7 \mathrm{~m}$ & Surut & & & & \\
\hline \multirow[t]{2}{*}{19} & $06.40 \mathrm{AM}$ & $0,2 \mathrm{~m}$ & Surut & 2,5 & 0,8 & 20 & 40 \\
\hline & $12.55 \mathrm{PM}$ & $2.7 \mathrm{~m}$ & Pasang & & & & \\
\hline \multirow[t]{2}{*}{20} & $07.20 \mathrm{AM}$ & $0,2 \mathrm{~m}$ & Surut & 2,6 & 0,8 & 20 & 41,6 \\
\hline & $13.35 \mathrm{PM}$ & $2,8 \mathrm{~m}$ & Pasang & & & & \\
\hline \multirow[t]{2}{*}{21} & $07.45 \mathrm{AM}$ & $0,3 \mathrm{~m}$ & Surut & 1,7 & 0,8 & 20 & 27,2 \\
\hline & 14.10 PM & $2 \mathrm{~m}$ & Pasang & & & & \\
\hline \multirow[t]{2}{*}{22} & $08.15 \mathrm{AM}$ & $0,3 \mathrm{~m}$ & Surut & 1,7 & 0,8 & 20 & 27,2 \\
\hline & $14.50 \mathrm{PM}$ & $2 \mathrm{~m}$ & Pasang & & & & \\
\hline \multirow[t]{2}{*}{23} & $08.55 \mathrm{AM}$ & $0,5 \mathrm{~m}$ & Surut & 1,5 & 0,8 & 20 & 24 \\
\hline & $15.20 \mathrm{PM}$ & $2 \mathrm{~m}$ & Pasang & & & & \\
\hline \multirow[t]{2}{*}{24} & $09.40 \mathrm{AM}$ & $0,7 \mathrm{~m}$ & Surut & 1,3 & 0,8 & 20 & 20,8 \\
\hline & $16.00 \mathrm{PM}$ & $2 \mathrm{~m}$ & Pasang & & & & \\
\hline \multirow[t]{2}{*}{25} & $10.40 \mathrm{AM}$ & $0,8 \mathrm{~m}$ & Surut & 1,2 & 0,8 & 20 & 19,2 \\
\hline & $16.55 \mathrm{PM}$ & $2 \mathrm{~m}$ & Pasang & & & & \\
\hline \multirow[t]{2}{*}{26} & $05.40 \mathrm{AM}$ & $1,9 \mathrm{~m}$ & Pasang & 1,3 & 0,8 & 20 & 20,8 \\
\hline & 11.20 PM & $0,6 \mathrm{~m}$ & Surut & & & & \\
\hline \multirow[t]{2}{*}{27} & $06.50 \mathrm{AM}$ & $1,9 \mathrm{~m}$ & Pasang & 0,9 & 0,8 & 20 & 14,4 \\
\hline & $12.20 \mathrm{PM}$ & $1 \mathrm{~m}$ & Surut & & & & \\
\hline \multirow[t]{2}{*}{28} & $08.20 \mathrm{AM}$ & $1,9 \mathrm{~m}$ & Pasang & 0,4 & 0,8 & 20 & 6,4 \\
\hline & $13.30 \mathrm{PM}$ & $1.5 \mathrm{~m}$ & Surut & & & & \\
\hline \multirow[t]{2}{*}{29} & $09.20 \mathrm{AM}$ & $2 \mathrm{~m}$ & Pasang & 0,7 & 0,8 & 20 & 11,2 \\
\hline & 14.40 PM & $1,3 \mathrm{~m}$ & Surut & & & & \\
\hline \multirow[t]{2}{*}{30} & $10.10 \mathrm{AM}$ & $2 \mathrm{~m}$ & Pasang & 1 & 0,8 & 20 & 16 \\
\hline & $15.30 \mathrm{PM}$ & $1 \mathrm{~m}$ & Surut & & & & \\
\hline \multirow[t]{2}{*}{31} & $10.55 \mathrm{AM}$ & $2,9 \mathrm{~m}$ & Pasang & 2,1 & 0,8 & 20 & 33,6 \\
\hline & $16.25 \mathrm{PM}$ & $0,8 \mathrm{~m}$ & Surut & & & & \\
\hline \multicolumn{7}{|c|}{ Energi Listrik rata-rata yang dihasilkan } & 26,89 \\
\hline
\end{tabular}

Rumus $\quad: \mathrm{P}=\mathrm{fQ} \mathrm{H}$

$\mathrm{P} \quad$ = Daya yang dihasilkan (Kwatt)

$\mathrm{f}=$ Faktor efisiensi $(80 \%)$ 


$$
\begin{array}{ll}
\mathrm{Q} & =\text { Debit air }\left(20 \mathrm{~m}^{3} / \text { detik }\right) \\
\mathrm{H} & =\text { Tinggi pasang surut terbesar }
\end{array}
$$

Hasil pengukuran yang diperoleh bahwa untuk nilai pasang surut tertinggi adalah 2.8 m. Sehingga daya yang dihasilkan adalah 44.8 Kwatt. Sedangkan kebutuhan masyarakat Kampung Tua Tanjung Gundap adalah 72.21. Sehingga masih diperlukan tambahan energi alternatif lainnya.

\begin{tabular}{|c|c|c|}
\hline Bulan September 2015 & Pukul & Kecepatan Angin \\
\hline \multirow[t]{2}{*}{1} & 09.15 & $1.7 \mathrm{~m} / \mathrm{s}$ \\
\hline & 15.15 & $1.7 \mathrm{~m} / \mathrm{s}$ \\
\hline \multirow[t]{2}{*}{2} & 08.20 & $1.7 \mathrm{~m} / \mathrm{s}$ \\
\hline & 16.15 & $4.2 \mathrm{~m} / \mathrm{s}$ \\
\hline \multirow[t]{2}{*}{3} & 09.20 & $3.1 \mathrm{~m} / \mathrm{s}$ \\
\hline & 17.00 & $3.1 \mathrm{~m} / \mathrm{s}$ \\
\hline \multirow[t]{2}{*}{4} & 08.45 & $2.7 \mathrm{~m} / \mathrm{s}$ \\
\hline & 17.10 & $3.1 \mathrm{~m} / \mathrm{s}$ \\
\hline \multirow[t]{2}{*}{5} & 08.10 & $1.7 \mathrm{~m} / \mathrm{s}$ \\
\hline & 16.15 & $2.4 \mathrm{~m} / \mathrm{s}$ \\
\hline \multirow[t]{2}{*}{6} & 08.20 & $1.7 \mathrm{~m} / \mathrm{s}$ \\
\hline & 17.30 & $2.4 \mathrm{~m} / \mathrm{s}$ \\
\hline \multirow[t]{2}{*}{7} & 09.00 & $2.5 \mathrm{~m} / \mathrm{s}$ \\
\hline & 16.05 & $1.9 \mathrm{~m} / \mathrm{s}$ \\
\hline \multirow[t]{2}{*}{8} & 08.15 & $3.8 \mathrm{~m} / \mathrm{s}$ \\
\hline & 16.25 & $2.3 \mathrm{~m} / \mathrm{s}$ \\
\hline \multirow[t]{2}{*}{9} & 09.00 & $2.6 \mathrm{~m} / \mathrm{s}$ \\
\hline & 16.15 & $1.5 \mathrm{~m} / \mathrm{s}$ \\
\hline \multirow[t]{2}{*}{10} & 09.20 & $3.8 \mathrm{~m} / \mathrm{s}$ \\
\hline & 17.00 & $2.6 \mathrm{~m} / \mathrm{s}$ \\
\hline \multirow[t]{2}{*}{11} & 08.45 & $4.0 \mathrm{~m} / \mathrm{s}$ \\
\hline & 17.10 & $3.7 \mathrm{~m} / \mathrm{s}$ \\
\hline \multirow[t]{2}{*}{12} & 08.10 & $3.0 \mathrm{~m} / \mathrm{s}$ \\
\hline & 16.15 & $2.6 \mathrm{~m} / \mathrm{s}$ \\
\hline \multirow[t]{2}{*}{13} & 08.20 & $2.9 \mathrm{~m} / \mathrm{s}$ \\
\hline & 17.30 & $1.0 \mathrm{~m} / \mathrm{s}$ \\
\hline \multirow[t]{2}{*}{14} & 09.00 & $3.4 \mathrm{~m} / \mathrm{s}$ \\
\hline & 16.05 & $1.4 \mathrm{~m} / \mathrm{s}$ \\
\hline \multirow[t]{2}{*}{15} & 08.15 & $3.0 \mathrm{~m} / \mathrm{s}$ \\
\hline & 16.25 & $1.7 \mathrm{~m} / \mathrm{s}$ \\
\hline 16 & 09.00 & $2.9 \mathrm{~m} . \mathrm{s}$ \\
\hline
\end{tabular}

\section{Analisis Potensi Energi Angin}




\begin{tabular}{|c|c|c|}
\hline & 16.15 & $1.8 \mathrm{~m} . \mathrm{s}$ \\
\hline \multirow[t]{2}{*}{17} & 08.35 & $3.0 \mathrm{~m} / \mathrm{s}$ \\
\hline & 16.20 & $2.7 \mathrm{~m} / \mathrm{s}$ \\
\hline \multirow[t]{2}{*}{18} & 08.57 & $3.3 \mathrm{~m} / \mathrm{s}$ \\
\hline & 16.17 & $2.7 \mathrm{~m} / \mathrm{s}$ \\
\hline \multirow[t]{2}{*}{19} & 08.30 & $3.1 \mathrm{~m} / \mathrm{s}$ \\
\hline & 16.20 & $1.8 \mathrm{~m} / \mathrm{s}$ \\
\hline \multirow[t]{2}{*}{20} & 09.15 & $3.0 \mathrm{~m} / \mathrm{s}$ \\
\hline & 15.15 & $2.6 \mathrm{~m} / \mathrm{s}$ \\
\hline \multirow[t]{2}{*}{21} & 08.20 & $3.1 \mathrm{~m} / \mathrm{s}$ \\
\hline & 16.15 & $1.9 \mathrm{~m} / \mathrm{s}$ \\
\hline \multirow[t]{2}{*}{22} & 09.20 & $2.7 \mathrm{~m} / \mathrm{s}$ \\
\hline & 17.00 & $2.9 \mathrm{~m} / \mathrm{s}$ \\
\hline \multirow[t]{2}{*}{23} & 08.45 & $3.0 \mathrm{~m} / \mathrm{s}$ \\
\hline & 17.10 & $1.9 \mathrm{~m} / \mathrm{s}$ \\
\hline \multirow[t]{2}{*}{24} & 08.10 & $2.9 \mathrm{~m} / \mathrm{s}$ \\
\hline & 16.15 & $3.9 \mathrm{~m} / \mathrm{s}$ \\
\hline \multirow[t]{2}{*}{25} & 08.20 & $3.2 \mathrm{~m} / \mathrm{s}$ \\
\hline & 17.30 & $2.1 \mathrm{~m} / \mathrm{s}$ \\
\hline \multirow[t]{2}{*}{26} & 09.00 & $2.1 \mathrm{~m} / \mathrm{s}$ \\
\hline & 16.05 & $1.0 \mathrm{~m} / \mathrm{s}$ \\
\hline \multirow[t]{2}{*}{27} & 08.15 & $3.5 \mathrm{~m} / \mathrm{s}$ \\
\hline & 16.25 & $1.0 \mathrm{~m} / \mathrm{s}$ \\
\hline \multirow[t]{2}{*}{28} & 09.00 & $3.9 \mathrm{~m} / \mathrm{s}$ \\
\hline & 16.15 & $2.0 \mathrm{~m} / \mathrm{s}$ \\
\hline \multirow[t]{2}{*}{29} & 09.20 & $1.9 \mathrm{~m} / \mathrm{s}$ \\
\hline & 17.00 & $2.7 \mathrm{~m} / \mathrm{s}$ \\
\hline \multirow[t]{2}{*}{30} & 08.45 & $3.9 \mathrm{~m} / \mathrm{s}$ \\
\hline & 17.10 & $2.8 \mathrm{~m} / \mathrm{s}$ \\
\hline
\end{tabular}

\section{Rumus}

$\mathrm{P}=1 / 2 \times \mathrm{C} \times \varsigma \times \mathrm{v} 3$

P : Daya Listri (KWatt/m)

C : Koefisien Energi Maksimum $(0,6)$

$\varsigma \quad$ : Densitas udara $\left(1,18 \mathrm{Kg} / \mathrm{m}^{2}\right)$

$\mathrm{v}:$ Kecepatan angin rata-rata $(\mathrm{m} / \mathrm{s})$

Hasil pengukuran yang diperoleh bahwa angin rata-rata bulan September adalah 2.6 $\mathrm{m} / \mathrm{s}$. Sehingga diperoleh daya listrik sebesar:

$\mathrm{P}=1 / 2 \times \mathrm{C} \times \varsigma \times \mathrm{v}^{3}$

$\mathrm{P}=1 / 2 \times 0,6 \times 1,18 \times(2,6)^{3}=6,22 \mathrm{Kwatt}$ 


\section{Analisis Potensi Energi Pasang Surut dan Energi Angin}

Energi pasang surut menghasilkan 44,8 Kwatt. Kemudian energi angin menghasilkan 6,22 Kwatt. Maka jumlah keseluruhan adalah 51,02. Sehingga dapat disimpulkan Kampung Tua Tanjung Gundap belum layak untuk direncanakan dan dibangun pembangkit listrik energi alternatif. Dengan pertimbangan beban puncak adalah 72,21 Kwatt.

\section{Analisis Kelayakan Sosial, Budaya dan Ekonomi}

Secara sosial budaya kehidupan masyarakat kampung tua Tanjung Gundap hampir sama dengan masyarakat pesisir pada umumnya. Hidup berdampingan dan saling kenal satu sama lain. Biasanya juga satu rumah dan rumah lainnya mempunyai jalinan kekeluargaan.

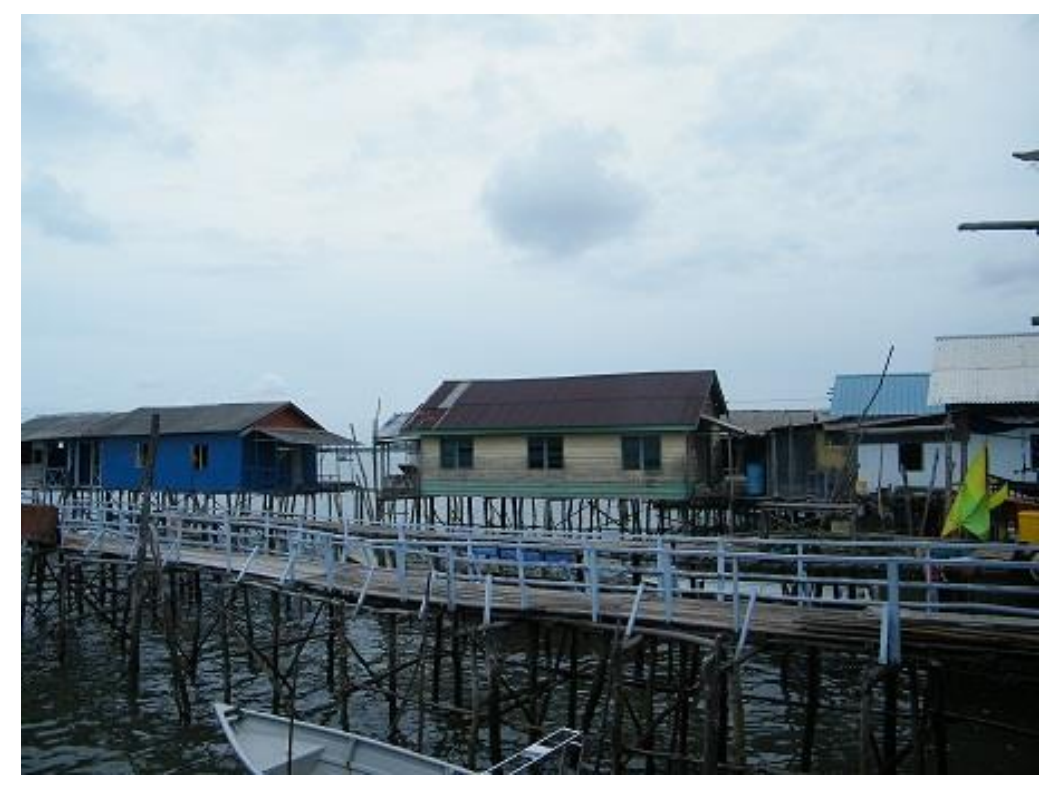

Dipandang dari segi kemasyarakatan, masyarakat kampung tua Tanjung Gundap sangat layak untuk dikembangkan. Banyak faktor yang mempengaruhinya. Dari segi jarak ke kota Batam, hanya berjarak kurang lebih $2 \mathrm{~km}$. Dengan lalu lintas yang ramai. Di kiri dan kanan jalan raya pemukiman warga. Dibutuhkan $3 \mathrm{~km}$ dari jalan raya untuk sampai ke Kampung Tua Tanjung Gundap dengan kondisi jalan masih merupakan tanah merah tidak beraspal.

Kondisi jalan menuju Tanjung Gundap masih berupa tanah merah. Jika hujan turun, kondisi aslinya sangat licin dan berair. Sulit dilalui kendaraan. Tidak adanya akses angkutan umum menuju kampung tua Tanjung Gundap juga mempengaruhi terbatasnya mobilitas masyarakat. Mobilitas penduduk berpangku pada kendaraan roda dua milik pribadi.

Adapun hasil analisis kuisioner yang telah dirancang :

1. Hampir semua masyarakat menempati rumah sendiri/ tidak menyewa. Terdapat $9 \%$ yang menempati satu rumah 2 keluarga. Dengan jumlah kamar berkisar 2-3 kamar. 
2. Wilayah dapat dikembangkan jika wilayah tersebut tidak dalam sengketa. Maknanya status tanah adalah sepenuhnya hak milik. Sementara situasi dan kondisi di Batam berbeda dengan wilayah Indonesia pada umumnya. Semua tanah di Batam hanyalah hak guna bukan hak milik. Sehingga rumah-rumah yang dibangun tanpa surat dan sudah turun temurun ditempati masih tersangkut di pemerintahan. Sebanyak $46,8 \%$ masyarakat Kampung Tua Tanjung Gundap mengatakan pernah terjadi penggusuran dalam kurun waktu 5 tahun terakhir.

3. Semua masyarakat Kampung Tua sudah memiliki WC/Toilet sendiri di dalam rumah. Walau WC yang dibangun belum memenuhi standar. WC biasanya bukan memakai septitank/ lubang pembuangan. Namun kotoran langsung jatuh ke air. Ditambah $100 \%$ masyarakat Kampung Tua tinggal di tepi laut.

4. Air bersih untuk kebutuhan sehari-hari masyarakat didapat dari tadah hujan. Semua rumah memiliki bak-bak penampungan. Sekitar $30 \%$ masyarakat mengandalkan sumber air bersihnya dari sumur bor. Jika musim kemarau tiba, biasanya rumah yang memiliki sumur bor menjadi pemasok air bersih bagi sekelilingnya. Namun kemarau yang terjadi di awal tahun 2015 menyisakan kekeringan di Tanjung Gundap. Sehingga antara bulan Februari-April 2015 semua masyarakat Kampung Tua membeli air bersih dari pemasok di luar Tanjung Gundap.

5. Setiap hari manusia memenuhi kebutuhan dasarnya dengan makanan. Sisa dari makanan harusnya bisa diolah sehingga tidak mencemari lingkungan. Namun 93,8 \% masyarakat Tanjung Gundap tidak memiliki tempat pembuangan sampah. Sehingga sampah dibuang di kolong rumah dan berserakan. Jika terjadi pasang, biasaya sampah ikut ke laut melalui gulungan ombak. Akan tetapi jika surut maka sampah ada dimanamana. 

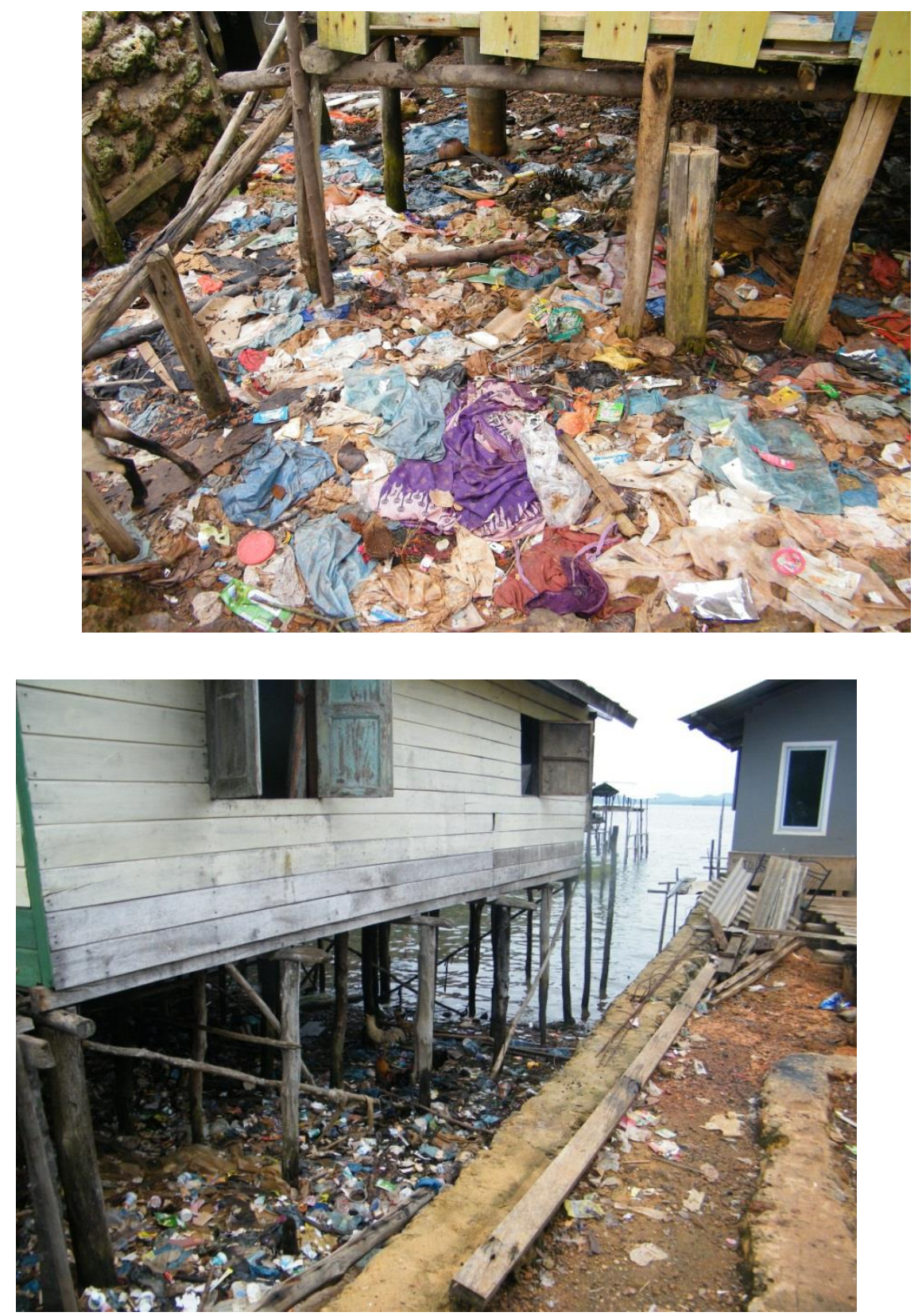

6. Standar kebutuhan air bersih per kapita untuk pedesaan 60 liter/hari/kapita. Sementara kebutuhan air bersih masyarakat Tanjung Gundap $94 \%$ di bawah rata-rata (20 - 40 liter/hari/kapita). Dan $6 \%$ (rata-rata 60 liter/hari/kapita) sesuai standar nasional.

7. Salah satu indikator yang perlu diperhatikan dalam pengembangan satu wilayah adalah keamanan. Dalam hal ini tanjung gundap $100 \%$ aman. Tidak pernah terjadi pencurian dan tindak kejahatan lainnya (pemerkosaan dll).

8. Transportasi adalah hal vital yang harus dimiliki satu daerah berkembang. Untuk sampai di Tanjung gundap satu-satunya adalah dengan kenderaan pribadi. Kira-kira 13 \% penduduk Tanjung Gundap memiliki mobil pribadi dan 53 \% memiliki 1 sepeda motor 
sebagai alat transportasi dan $32 \%$ memiliki 2 sepeda motor/keluarga. Tingginya kepemilikan kenderaan pribadi dikarenakan tidak adanya transportasi umum yang disediakan pemerintah ke Tanjung Gundap.

9. Banyaknya pengangguran juga menentukan tinggi atau rendahnya perkembangan satu daerah. Rata-rata masyarakat Tanjung Gundap bermata pencaharian nelayan (87,5 \%). Sisanya wiraswasta dan lain-lain sebanyak $12,5 \%$ (PNS dan lain-lain).

10. Wanita yang identik dengan pekerjaan rumah tangga tidak begitu populer saat ini. Biasanya wanita juga berinisiatif mencari tambahan penghasilan dengan pekerjaan sampingan. Sebanyak 31,25 \% ibu rumah tangga di Tanjung Gundap memiliki pekerjaan sampingan, diantaranya : berdagang, membuat tudung saji dari pelepah kelapa, membuat kerupuk ikan, mengeringkan ikan, melayani catering makanan laut dan lainlain. Namun dari pekerjaan sampingan tersebut kecuali berdagang masih harus bergantung kepada hasil laut yang dihasilkan suaminya. Sehingga tidak banyak perkembangan ekonomi yang terlihat.

11. Tingginya tingkat pendidikan suatu masyarakat menentukan kualitas kehidupan di wilayah tersebut. Pendidikan masih merupakan barang mahal yang dimiliki oleh masyarakat pesisir. Begitu juga yang terjadi di Tanjung Gundap. Kurang lebih 65,6 \% masyarakatnya adalah lulusan sekolah dasar, 18,75 \% lulusan sekolah menengah pertama, 12,5 \% lulusan sekolah menengah atas dan 3,1 \% lulusan universitas.

12. Budaya lokal adalah hal menarik yang dapat dikembangkan. Orang asing selalu tertarik dengan budaya Indonesia yang begitu beragam. Namun untuk mempromosikan budaya sebagai objek wisata dibutuhkan indikator pendukung yang memadai. Tanjung Gundap sendiri tidak pernah dikunjungi oleh orang asing dengan tujuan wisata. Kedatangan orang asing biasanya bukan sebagai pengunjung melainkan untuk bekerja di beberapa perusahaan yang berdekatan dengan Tanjung Gundap.

Tanjung Gundap adalah wilayah yang harus dikembangkan. Banyak hal menarik yang dapat dijadikan sumber perkembangan sosial,ekonomi dan budaya. Namun kondisi alam Tanjung Gundap belum relevan untuk diterapkan elektrifikasi hibrid.

\section{KESIMPULAN}


1. Menurut data yang telah dihimpun dari tanggal 13 Mei - 30 September 2015 bahwa perancangan pembangkit listrik energi alternatif belum layak dibangun di Tanjung Gundap. Karena energi yang akan dihasilkan lebih sedikit dari beban listrik yang dibutuhkan masyarakat.

2. Hasil kuisioner kelayakan sosial, ekonomi dan budaya adalah Tanjung Gundap kategori pada kategori belum layak dengan beberapa alasan: sanitasi yang tidak mumpuni, perumahan yang tidak layak huni, sumber daya manusia yang belum profesional, jalur transportasi yang sulit dilalul.

\section{SARAN}

1. Dilakukan pengujian ulang mengenai sumber daya alam yang dapat digunakan sebagai sumber listrik

2. Penelitian dilakukan dalam jangka waktu yang relatif lebih panjang sehingga didapat hasil maksimal energi pasang surut air laut dan energi angin.

3. Diperbaiki insfrastruktur, tata letak, sanitasi, akses transportasi dan semua fasilitas umum dengan kerjasama dengan pemerintah kota dan provinsi.

\section{DAFTAR PUSTAKA}

- Ahmad Agus Setiawan, Y. Z. (2008), "Design, economic analysis and environmental considerations of mini-grid hybrid power system with reverse osmosis desalination plant for remote areas", Elsevier, 34, 374-383.

- Elbani, A., (2013), "Model Pembangkit Lisrik Tenaga Diesel (PLTD), Berbasis pada Sinyal Masukan Bahan Bakar dan Daya Keluaran Dengan Metoda Identifikasi Parameter", ELKHA, Vol.5 No 2, Oktober 2013.

- Faten Hosney Fahmy, N. M. (2012), “Optimization of Renewable Energy Power System for Small Scale Brackish Reverse Osmosis Desalination Unit and a Tourism Motel in Egypt", Scientific Research (doi:10.4236/sgre.2012.31006 Published Online February 2012 (http://www.SciRP.org/journal/sgre)), 43-50.

- Juwito, A. F, Sasongko P., T, Haryono (2012), “Optimalisasi Energi Terbarukan pada Pembangkit Tenaga Listrik dalam Menuju Desa Mandiri Energi di Margajaya”, Jurnal Ilmiah Semesta Teknika, vol. 15 no. 1, Mei 2012, hal. 22-34.

- Kunaifi, (2010), "Program Homer untuk Studi Kelayakan Pembangkit Listrik Hibrida di Propinsi Riau", Seminar Nasional Informatika 2010 (semnasIF 2010), UPN "Veteran" Yogyakarta, 18. 
- Meng, X. (2011), "Feasibility Analysis of Renewable Power Supply System for Remote SuoNanDaJie Protect Station”. IEEE Computer Society (978-0-76954501-1/11 \$26.00 (C 2011 IEEE), 148.

- Mubiru, J. and Banda, E.J.K.B. (2008), "Estimation of monthly average daily global solar irradiation using artificial neural network”, Solar Energy 82, 181- 187.

- Rosentrom, U. And Mickwitz, P. (2004), "Social and cultural indicators supporting the measurement of eco-efficiency in the Kymenlaakso region", Finnish Enviroment Institude Article.

- Sangari, Ferry, J. (2012), "Rancangan dan Uji Coba Prototipe Pembangkit Listrik Pasang Surut di Sulawesi Utara”, Jurnal Ilmiah Elite Elektro, Vol. 3 no. 1, Maret 2012.

- Tantrawati, E., Ruzardi (2007), "Potensi Pembangkit Listrik Tenaga Pasang Surut Sistem Daur Ganda Dengan Kolam Tunggal di Sumatra”, Jurnal LOGIKA, Vol. 4 No. 1, Januari 2007 